\title{
PROFIL TUMOR JINAK KULIT DI POLIKLINIK \\ KULIT DAN KELAMIN RSUP PROF. DR. R. D KANDOU MANADO PERIODE 2009-2011
}

\author{
${ }^{1}$ Grace Agustin Gefilem \\ ${ }^{2}$ Pieter Levinus Suling \\ ${ }^{2}$ Marlyn Grace Kapantouw
}

\author{
${ }^{1}$ Kandidat Skripsi Fakultas Kedokteran Universitas Sam Ratulangi Manado \\ ${ }^{2}$ Bagian/SMF Ilmu Kesehatan Kulit dan Kelamin Fakultas Kedokteran Universitas \\ Sam Ratulangi Manado \\ agustin.gefilem@gmail.com
}

\begin{abstract}
:
Introduction: Benign skin tumor manifestation of chaos skin growths that are congenital or akuisita, without the invasive and metastatic tendency, can be derived from vascular and non-vascular. Benign tumors was often said to be dangerouly because it is not develop into malignant tumors, howver skin tumor needs to be understood because causing disability (ruin the appearance) and also at an advanced stage can be fatal in body health.

Objective: To know the profile of patients benign skin tumor, age, gender and employment in the Dermatology Clinic Dr Prof Dr. R. D. Kandou Manado for 3 years (January 2009 - December 2011). Subjects and Methods: A retrospective study of benign skin tumor of the medical records of new patients based on tumor type, age, sex, and occupation.

Results: There were $478(15.65 \%)$ patients of benign skin tumor among 3055 new patients. Verruca vulgaris (28.03\%) and seborrheic keratosis (24.69\%) most frequently encountered. Highest age group is $15-44$ years is $49.16 \%$. The ratio of men and women for benign skin tumor is 1:1,12. Most jobs are housewives (26.36\%). Conclusion: verruca vulgaris is the most benign skin tumor. Benign skin tumor was more common in women. Highest age group is 15-44 years. Most jobs are housewives.
\end{abstract}

Keywords: skin tumors, benign 


\begin{abstract}
Abstrak
Pendahuluan: Tumor jinak kulit merupakan manifestasi dari kekacauan pertumbuhan kulit yang bersifat kongenital atau akuisita, tanpa tendensi invasif dan metastasis, dapat berasal dari vaskuler dan non vaskuler. Tumor jinak sering dikatakan tidak berbahaya karena tidak sampai berkembang menjadi keganasan namun demikian, tumor kulit perlu dipahami karena selain menyebabkan kecacatan (merusak penampilan) juga pada stadium lanjut dapat berakibat fatal kesehatan tubuh.

Tujuan: Mengetahui profil pasien tumor jinak kulit berdasarkan jenis tumor, umur, jenis kelamin dan pekerjaan di Poliklinik Kulit dan Kelamin RSUP Prof Dr. R. D. Kandou Manado selama 3 tahun (Januari 2009- Desember 2011).

Subyek dan Metode: Penelitian retrospektif tumor jinak kulit terhadap catatan medis kasus baru berdasarkan jenis tumor, usia, jenis kelamin, dan pekerjaan.

Hasil: Terdapat $478(15,65 \%)$ pasien tumor jinak kulit di antara 3055 pasien baru. Veruka vulgaris $(28,03 \%)$ dan keratosis seboroik $(24,69 \%)$ paling sering dijumpai. Kelompok usia terbanyak adalah 15-44 tahun sejumlah 49,16\%. Rasio laki-laki dan perempuan untuk tumor jinak kulit ialah 1:1,12. Pekerjaan terbanyak ialah ibu rumah tangga $(26,36 \%)$.

Kesimpulan: Veruka vulgaris merupakan tumor kulit jinak terbanyak. Tumor kulit jinak lebih sering terjadi pada perempuan. Kelompok usia tertinggi adalah 15-44 tahun. Pekerjaan terbanyak adalah ibu rumah tangga.
\end{abstract}

Kata kunci: tumor kulit, jinak

\section{PENDAHULUAN}

Tumor berasal dari bahasa latin tumere yang berarti membengkak. Tumor dapat diartikan pula sebagai pembengkakan, suatu tanda kardinal peradangan; pembesaran yang morbid atau pertumbuhan baru suatu jaringan dengan multiplikasi sel- sel yang tidak terkontrol dan progresif; disebut juga neoplasma. ${ }^{1,2,3}$

Tumor dapat timbul dalam tubuh akibat pengaruh berbagai faktor penyebab yang akhirnya menyebabkan jaringan setempat pada tingkat gen kehilangan kendali normal atas pertumbuhannnya. ${ }^{4}$

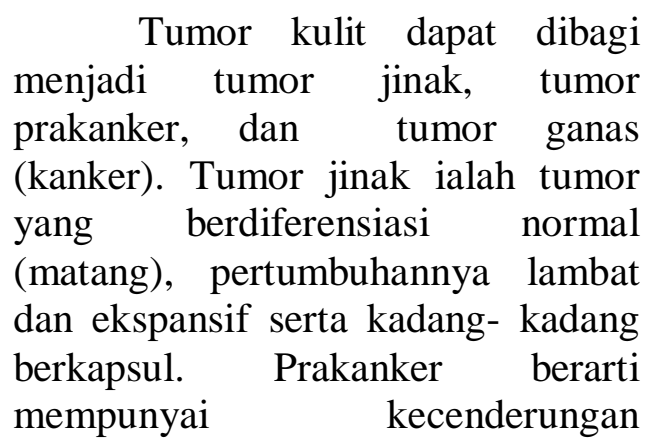

bekembang menjadi kanker (tumor ganas) sedangkan, tumor ganas (kanker) ialah tumor yang bersifat infiltratif sampai merusak jaringan disekitarnya serta bermetastasis melalui pembuluh darah dan atau pembuluh getah bening. ${ }^{5}$

$\begin{array}{ccc}\text { Tumor } & \text { jinak } & \text { kulit } \\ \text { merupakan } & \text { manifestasi } & \text { dari }\end{array}$
kekacauan pertumbuhan kulit yang bersifat kongenital atau akuisita, tanpa tendensi invasif dan metastasis, dapat berasal dari vaskuler dan non vaskuler. ${ }^{6}$ Tumor jinak dapat mendesak jaringan organ sekitarnya, namun biasanya tidak berinfiltrasi merusak jaringan disekitarnya, sehingga bahayanya relatif kecil. ${ }^{4}$

Penyakit tumor pada kulit dewasa ini cenderung mengalami peningkatan jumlah terutama di Amerika, Australia, dan Inggris. Berdasarkan beberapa penelitian, orang kulit putih yang lebih banyak 
menderita tumor kulit. Hal tersebut diprediksikan sebagai akibat seringnya terkena (banyak terpajan) cahaya matahari. Di Indonesia penderita tumor kulit terbilang sangat sedikit dibandingkan ke-3 negara tersebut, namun demikian tumor kulit perlu dipahami karena selain menyebabkan kecacatan (merusak penampilan) juga pada stadium lanjut dapat berakibat fatal. ${ }^{7}$

Tumor jinak sering dikatakan tidak berbahaya karena tidak sampai berkembang menjadi kanker namun demikian, penyakit ini tetap tidak bisa dianggap remeh karena dapat berakibat fatal pada kesehatan tubuh. Sifatnya yang jinak membuat penderita kurang tanggap melakukan pengobatan padahal, semakin cepat penyakit tumor jinak diobati akan semakin baik hasilnya. ${ }^{8}$

Jumlah penderita tumor semakin meningkat beberapa tahun belakangan ini. ${ }^{5}$ Indonesia termasuk negara tropis dengan sinar ultraviolet dari matahari sangat kuat dan sebagian besar masyarakat banyak melakukan aktivitas yang langsung terpajan sinar matahari, sehingga berpengaruh pada proses terjadinya tumor kulit. ${ }^{6}$

Beberapa tumor kulit jinak yang sering dijumpai adalah keratosis seboroik, veruka vulgaris, dan keloid. ${ }^{9}$

Penelitian yang dilakukan oleh Wijaya, menunjukkan bahwa terdapat $482(16,37 \%)$ pasien tumor kulit jinak di antara 2.945 pasien baru. Veruka vulgaris merupakan tumor kulit jinak terbanyak. Tumor kulit jinak lebih sering terjadi pada perempuan. Kelompok usia tertinggi adalah 15-44 tahun. Pekerjaan terbanyak adalah ibu rumah tangga 9
Tujuan penelitian ini ialah untuk mengetahui profil pasien tumor jinak berdasarkan jenis tumor, umur, jenis kelamin dan pekerjaan di Poliklinik Kulit dan Kelamin RSUP Prof Dr. R. D. Kandou Manado periode Januari 2009- Desember 2011.

\section{METODOLOGI}

Penelitian dilakukan secara retrospektif deskriptif dengan mengevaluasi catatan rekam medik kasus baru tumor kulit jinak di Poliklinik Kulit dan Kelamin RSUP Prof Dr. R. D. Kandou Manado dalam jangka waktu 2 bulan yaitu dari bulan November - Desember 2011.

\section{VARIABEL PENELITIAN}

Variabel yang dievaluasi dalam penelitian ini meliputi jenis tumor jinak kulit yang ditemukan adalah usia, jenis kelamin, dan pekerjaan.

\section{HASIL PENELITIAN}

Pada hasil evaluasi retrospektif yang dilakukan di poliklinik kulit dan kelamin RSUP Prof. dr. R. D. Kandou Manado sejak Januari 2009 sampai Desember 2011, terdapat 478 $(15,65 \%)$ pasien baru dengan tumor kulit jinak dari 3055 total pasien baru poliklinik kulit dan kelamin (Tabel 1). 
Tabel 1. Jumlah kunjungan pasien baru dengan tumor kulit

\begin{tabular}{|c|c|c|c|c|}
\hline \multirow{2}{*}{ Jumlah kunjungan } & \multicolumn{3}{|c|}{ Tahun } & \multirow{2}{*}{ Jumlah } \\
\hline & 2009 & 2010 & 2011 & \\
\hline Total pasien baru poliklinik kulit dan kelamin & 1001 & 1041 & 1013 & 3055 \\
\hline Pasien baru dengan tumor kulit jinak & 163 & 181 & 134 & 478 \\
\hline $\begin{array}{l}\% \text { pasien baru dengan tumor jinak kulit / } \\
\text { total pasien poliklinik kulit dan kelamin }\end{array}$ & $16.28 \%$ & $17.39 \%$ & $13.23 \%$ & $15.65 \%$ \\
\hline
\end{tabular}

Dari 20 jenis tumor kulit jinak, teridentifikasi dua penyakit tumor junak kulit terbanyak adalah veruka vulgaris sebanyak 134 (28,03\%) kasus dan keratosis seboroik 118 (24,69\%) kasus (Tabel 2). 
Tabel 2. Sebaran jenis tumor jinak kulit

\begin{tabular}{lccccc}
\hline \multicolumn{1}{c}{ Diagnosis } & $\mathbf{2 0 0 9}$ & $\mathbf{2 0 1 0}$ & $\mathbf{2 0 1 1}$ & Jumlah & \% \\
\hline Veruka Vulgaris & 38 & 53 & 43 & 134 & 28.03 \\
Keratosis Seboroik & 54 & 44 & 20 & 118 & 24.69 \\
Keloid & 15 & 23 & 25 & 63 & 13.18 \\
Nevus Pigmentosus & 9 & 8 & 9 & 26 & 5.44 \\
Xanthelasma & 13 & 10 & 13 & 36 & 7.53 \\
Neurofibromatosis Tipe I & 8 & 7 & 4 & 19 & 3.97 \\
Kista Epidermal & 7 & 6 & 2 & 15 & 3.14 \\
Hemangioma & 6 & 4 & 1 & 11 & 2.30 \\
Siringoma & 5 & 2 & 2 & 9 & 1.88 \\
Nevus Melanositik & - & 7 & - & 7 & 1.46 \\
Steatokistoma Multipel & 2 & 2 & 3 & 7 & 1.46 \\
Veruka Plana & - & 4 & 3 & 7 & 1.46 \\
Nevus Epidermal & 2 & 2 & 2 & 6 & 1.26 \\
Lentigo Senilis & 1 & 4 & - & 5 & 1.05 \\
Lipoma & 1 & 1 & 3 & 5 & 1.05 \\
Xanthoma & 1 & 2 & - & 3 & 0.63 \\
Dermatofibroma & - & - & 3 & 3 & 0.63 \\
Nevus Sebaseus & 1 & 1 & - & 2 & 0.42 \\
Nevus Displastik & - & 1 & - & 1 & 0.21 \\
Nevus Becker & - & - & 1 & 1 & 0.21 \\
Jumlah (\%) & $\mathbf{1 6 3}$ & $\mathbf{1 8 1}$ & $\mathbf{1 3 4}$ & $\mathbf{4 7 8}$ & $\mathbf{1 0 0 . 0 0}$ \\
Persentase & $\mathbf{3 4 . 1 0 \%}$ & $\mathbf{3 7 . 8 7 \%}$ & $\mathbf{2 8 . 0 3 \%}$ & & \\
\hline
\end{tabular}

Sebaran menurut usia $1^{10}$, terbanyak pada kelompok usia 15- 44 tahun sebanyak total $235(49,16 \%)$ pasien (Tabel 3). 
Tabel 3. Sebaran usia pasien baru menurut jenis tumor jinak kulit

\begin{tabular}{lccccccc}
\hline Diagnosis & $\mathbf{0}-<\mathbf{1}$ & $\mathbf{1 - 1 4}$ & $\mathbf{1 5 - 4 4}$ & $\mathbf{4 5 - 6 4}$ & $\mathbf{2 6 5}$ & Jumlah & \% \\
\hline Veruka Vulgaris & & 49 & 60 & 18 & 7 & 134 & 28.03 \\
Keratosis Seboroik & - & 2 & 42 & 58 & 16 & 118 & 24.69 \\
Keloid & - & 7 & 43 & 10 & 3 & 63 & 13.18 \\
Nevus Pigmentosus & - & 2 & 16 & 7 & 1 & 26 & 5.44 \\
Xanthelasma & - & - & 11 & 23 & 2 & 36 & 7.53 \\
Neurofibromatosis Tipe I & - & 2 & 14 & 3 & - & 19 & 3.97 \\
Kista Epidermal & - & 2 & 7 & 4 & 2 & 15 & 3.14 \\
Hemangioma & - & 4 & 7 & - & - & 11 & 2.30 \\
Siringoma & - & 1 & 8 & - & - & 9 & 1.88 \\
Nevus Melanositik & - & 4 & 3 & - & - & 7 & 1.46 \\
Steatokistoma Multipel & - & - & 6 & 1 & - & 7 & 1.46 \\
Veruka Plana & - & - & 5 & 2 & - & 7 & 1.46 \\
Nevus Epidermal & - & - & 3 & 3 & - & 6 & 1.26 \\
Lentigo Senilis & - & - & - & 1 & 4 & 5 & 1.05 \\
Lipoma & - & - & 4 & 1 & - & 5 & 1.05 \\
Xanthoma & - & 1 & 2 & - & - & 3 & 0.63 \\
Dermatofibroma & - & - & 2 & 1 & - & 3 & 0.63 \\
Nevus Sebaseus & - & 1 & 1 & - & - & 2 & 0.42 \\
Nevus Displastik & - & 1 & - & - & - & 1 & 0.21 \\
Nevus Becker & - & - & 1 & - & - & 1 & 0.21 \\
Jumlah (\%) & - & $\mathbf{7 6}$ & $\mathbf{2 3 5}$ & $\mathbf{1 3 2}$ & $\mathbf{3 5}$ & $\mathbf{4 7 8}$ & $\mathbf{1 0 0 . 0 0}$ \\
Persentase & - & $\mathbf{1 5 . 9 0 \%}$ & $\mathbf{4 9 . 1 6 \%}$ & $\mathbf{2 7 . 6 2 \%}$ & $\mathbf{7 . 3 2 \%}$ & & \\
\hline
\end{tabular}

Veruka vulgaris menempati urutan terbanyak untuk tumor kulit jinak sebanyak 134 (28,03\%) kasus, dengan rasio laki-laki dan perempuan 1,06: 1 (lakilaki: 69 [51,49\%]; perempuan: 65 [48,51\%]). Secara keseluruhan, persentase pasien laki - laki dan perempuan 1: 1,12 (laki - laki: 226 [47,28\%]; perempuan: $252[52,72 \%])$ (Tabel 4). 
Tabel 4. Sebaran jenis kelamin pasien baru menurut jenis tumor jinak kulit

\begin{tabular}{lcccc}
\hline \multicolumn{1}{c}{ Diagnosis } & Laki - laki & Perempuan & Jumlah & \% \\
\hline Veruka Vulgaris & 69 & 65 & 134 & 28.03 \\
Keratosis Seboroik & 69 & 49 & 118 & 24.69 \\
Keloid & 29 & 34 & 63 & 13.18 \\
Nevus Pigmentosus & 3 & 23 & 26 & 5.44 \\
Xanthelasma & 7 & 29 & 36 & 7.53 \\
Neurofibromatosis Tipe I & 9 & 10 & 19 & 3.97 \\
Kista Epidermal & 7 & 8 & 15 & 3.14 \\
Hemangioma & 7 & 4 & 11 & 2.30 \\
Siringoma & 1 & 8 & 9 & 1.88 \\
Nevus Melanositik & 2 & 5 & 7 & 1.46 \\
Steatokistoma Multipel & 2 & 5 & 7 & 1.46 \\
Veruka Plana & 6 & 1 & 7 & 1.46 \\
Nevus Epidermal & 1 & 5 & 6 & 1.26 \\
Lentigo Senilis & 2 & 3 & 5 & 1.05 \\
Lipoma & 4 & 1 & 5 & 1.05 \\
Xanthoma & 3 & - & 3 & 0.63 \\
Dermatofibroma & 2 & 1 & 3 & 0.63 \\
Nevus Sebaseus & 2 & - & 2 & 0.42 \\
Nevus Displastik & - & 1 & 1 & 0.21 \\
Nevus Becker & 1 & - & 1 & 0.21 \\
Jumlah (\%) & $\mathbf{2 2 6}$ & $\mathbf{2 5 2}$ & $\mathbf{4 7 8}$ & $\mathbf{1 0 0 . 0 0}$ \\
Persentase & $\mathbf{4 7 2 8 \%}$ & $\mathbf{5 2 . 7 2 \%}$ & & \\
\hline
\end{tabular}

Seratus dua puluh enam pasien atau 26,36\% dari 478 pasien tumor kulit jinak memiliki pekerjaan sebagai ibu rumah tangga. Pekerjaan kedua terbanyak adalah pelajar, yaitu sebanyak 105 pasien (21,97\%) (Tabel 5). 
Tabel 5. Sebaran pekerjaan pasien baru dengan tumor jinak kulit

\begin{tabular}{lccccc}
\hline \multicolumn{1}{c}{ Pekerjaan } & $\mathbf{2 0 0 9}$ & $\mathbf{2 0 1 0}$ & $\mathbf{2 0 1 1}$ & Jumlah & \% \\
\hline Ibu Rumah Tangga & 56 & 48 & 22 & 126 & 26.36 \\
Pelajar & 23 & 36 & 46 & 105 & 21.97 \\
Pensiunan & 19 & 34 & 15 & 68 & 14.23 \\
PNS & 35 & 28 & 14 & 77 & 16.11 \\
Karyawan & 11 & 20 & 5 & 36 & 7.53 \\
Wiraswasta & 14 & 9 & 14 & 37 & 7.74 \\
Tidak Bekerja & 1 & 5 & 16 & 22 & 4.60 \\
Guru & 4 & 1 & 2 & 7 & 1.46 \\
Jumlah (\%) & $\mathbf{1 6 3}$ & $\mathbf{1 8 1}$ & $\mathbf{1 3 4}$ & $\mathbf{4 7 8}$ & $\mathbf{1 0 0 . 0 0}$ \\
Persentase & $\mathbf{3 4 . 1 0 \%}$ & $\mathbf{3 7 . 8 7 \%}$ & $\mathbf{2 8 . 0 3 \%}$ & & \\
\hline
\end{tabular}

\section{PEMBAHASAN}

Dari 3055 pasien baru di poliklinik kulit dan kelamin RSUP Prof. Dr. R. D. Kandou Manado sejak 1 Januari 2009 sampai 31 Desember 2011 didapatkan 478 (15,65\%) pasien dengan 20 jenis tumor jinak kulit (Tabel 1). Di antara kelompok pasien dengan tumor jinak kulit tersebut, veruka vulgaris (134 kasus; 28,03\%) dan keratosis seboroik (118 kasus; 24,69\%) merupakan tumor kulit jinak yang paling sering dijumpai (Tabel 2). Pada studi retrospektif yang dilakukan oleh Hamzah dkk. untuk tumor kulit RSUD Abdul Moeloek Lampung periode Januari 2006 Desember 2007 menunjukkan hasil bahwa keratosis seboroik menempati urutan pertama terbanyak untuk tumor kulit jinak $(29,2 \%)$ dari 355 pasien baru dengan tumor kulit. ${ }^{9,11}$ Studi retrospektif yang dilakukan oleh Wijaya dkk. untuk tumor kulit RSUP. Prof. Dr. R. D. Kandou Manado periode Januari 2008- Desember 2010 menunjukkan hasil bahwa veruka vulgaris menempati urutan pertama terbanyak untuk tumor kulit jinak $(27,39 \%)$ dari 482 pasien baru dengan tumor kulit. 9 Perbedaan hasil mengenai jenis tumor kulit terbanyak dari berbagai studi tersebut kemungkinan disebabkan oleh perbedaan dalam kriteria yang digunakan untuk mengelompokkan tumor kulit jinak. Terdapat banyak penggolongan tumor kulit, Rata menggolongkan tumor kulit jinak berdasarkan asal, predileksi, gambaran klinis, dan terapi. ${ }^{5}$ Thomas et al menyebutkan bahwa tidak ada keseragaman dalam sistem klasifikasi tumor kulit jinak karena asal dan gambaran klinis yang bervariasi. ${ }^{9,12}$ Literatur lain menggolongkan tumor kulit berdasarkan asal histologis, kelompok usia, lokasi, dan gambaran klinis mereka. ${ }^{9}$ Klasifikasi tumor kulit jinak dalam studi retrospektif ini diambil berdasarkan Kolegium Ilmu Kesehatan Kulit dan Kelamin Indonesia, tumor kulit jinak kulit dapat dibagi menjadi tumor jinak epidermis, kista epidermis, dan tumor jinak adneksa; tumor jinak melanosit dan sel nevus; tumor jinak jaringan ikat; tumor jinak jaringan lemak dan kelainan metabolisme lemak; tumor jinak karena virus; dan tumor jinak dan hiperplasia vaskular. ${ }^{9,10}$

Pada studi ini, veruka vulgaris ditemukan dengan jumlah sebanyak 134 kasus (28.88\%) (Tabel 2), dengan 
perbandingan 69 laki - laki dan 65 perempuan (1,06 : 1) (Tabel 4). Jumlah pasien terbanyak dari kelompok usia 14-59 tahun (345 dari 464 pasien [74,4\%]) (Tabel 3). Hasil ini sesuai dengan studi yang dilakukan oleh Wijaya dkk di Manado tahun 2008- 2009, dimana tidak terdapat perbedaan yang bermakna untuk jenis kelamin pasien. ${ }^{9}$ Tidak adanya perbedaan bermakna antara laki - laki dan perempuan ini kemungkinan berhubungan dengan Human Papilloma Virus (HPV) sebagai etiologi veruka vulgaris yang dapat menyerang laki - laki maupun perempuan.

Kelompok usia dengan kejadian tumor kulit jinak yang tertinggi adalah kelompok usia 14- 59 tahun sebanyak 345 (74.4\%) pasien (Tabel 3). Temuan ini sesuai dengan kepustakaan, yaitu veruka vulgaris dan keratosis seboroik merupakan tumor kulit jinak yang paling banyak ditemukan di usia pertengahan. ${ }^{9,13}$ Kelompok usia 15 - 44 tahun merupakan kelompok usia menurut $\mathrm{WHO}^{10}$ dengan rentang yang luas, sehingga kemungkinan hal inilah yang menyebabkan jumlah pasien dalam kelompok ini menjadi lebih tinggi dibandingkan kelompok usia yang lain selain mengingat bahwa rentang usia tersebut merupakan usia produktif dengan aktifitas yang tinggi.

Pekerjaan termasuk faktor yang berperan dalam pertumbuhan tumor. ${ }^{5}$ Pada studi ini, 117 pasien atau $25,22 \%$ dari 464 pasien tumor kulit jinak memiliki pekerjaan sebagai ibu rumah tangga. Pekerjaan kedua terbanyak adalah pelajar, yaitu sebanyak 105 pasien $(22,63 \%)$. (Tabel 5). Studi retrospektif yang dilakukan di RSUP H. Adam Malik Medan oleh Sibarani dkk. pada periode 2005 2009 menunjukkan bahwa 26,68\% dari 296 pasien tumor kulit memiliki pekerjaan sebagai pelajar. ${ }^{9}$ Studi retrospektif yang dilakukan di RSUP Prof. dr. R. D Kandou Manado oleh Wijaya priode 2008- 2009 menunjukkan bahwa 137 pasien $(28,42 \%)$ dari 482 pasien tumor kulit memiliki pekerjaan sebagai ibu rumah tangga dan $102(21,16 \%)$ memiliki pekerjaan sebagai pelajar. ${ }^{9}$ Tumor kulit jinak terbanyak dalam studi ini adalah veruka vulgaris dan keratosis seboroik, di mana pekerjaan memiliki peranan penting sebagai faktor predisposisi karena berhubungan dengan pajanan sinar matahari. Ibu rumah tangga dan pelajar memiliki aktivitas sehari - hari yang sebagian besar dilakukan di luar rumah sehingga banyak mendapat pajanan sinar matahari. ${ }^{9}$

\section{SIMPULAN}

Dari studi retrospektif rekam medik pasien baru dengan tumor kulit jinak pada seluruh pasien baru yang berobat ke Poliklinik Kulit dan Kelamin RSUP Prof. Dr. R. D. Kandou Manado periode Januari 2009 Desember 2011 didapatkan 20 jenis tumor jinak, di mana veruka vulgaris dan keratosis seboroik merupakan 2 terbanyak. Tumor kulit jinak lebih sering terjadi pada kelompok usia 15-44 tahun. Pasien perempuan lebih banyak dibandingkan laki - laki. Ibu rumah tangga adalah pertama pekerjaan terbanyak.

\section{UCAPAN TERIMA KASIH}

Ucupan terima kasih ditujukan kepada Dr. Renate T. Kandou, SpKK (K) selaku penguji I, Dr. Nurdjannah J. Niode, SpKK selaku penguji II, dan kepada semua pihak yang secara langsung maupun tidak langsung telah menumbuhkan gagasan dalm penulisan artikel ini.

\section{DAFTAR PUSTAKA}

1. Dorland, W.A.Newman. Kamus Kedokteran Dorland. Edisi 29. Jakarta : EGC; 2002. Tumor; p. 2312.

2. Master,FJ. 2005. Tumours and Homoeopathy avalaible online at http://www.narayanapublishers.com/homeopathy/pdf/Tumo urs-and-Homoeopathy-Farokh-J- 
Master.011872.pdf [Accessed 17 Januari 2013]

3. Brower, V. 2005. Feeding the Flame: New Research Adds to Role of Inflammation in Cancer Development avalaible online at http://jnci.oxfordjournals.org/content/9 7/4/251.full [Accessed 17 Januari 2013]

4. Desen W. Buku Ajar Onkologi Klinik. Edisi 2. Jakarta : Balai Penerbit FKUI; 2008.p.3.

5. Rata IG. Tumor Kulit. In : Djuanda A, editor. Ilmu Penyakit Kulit dan Kelamin. Edisi 5. Jakarta : Balai Penerbit FKUI; 2010. p.227-232.

6. Putra IB. Tumor- tumor jinak kulit [Tesis]. Medan : Universitas Sumatra Utara; 2008.

7. Amaliah B, Lailatul DW, Yuniarti A, Arieshanti I, Fatichah C, Widyanto MR. 2010. Penggunaan Persamaan Difusi Nonlinier dan Deteksi Tepi Canny Untuk Segmentasi Citra Melanoma avalaible online at http://www.its.ac.id/personal/files/pub /4588-chastine-SESINDO.pdf.

Accessed 17 Januari 2013]

8. Wirati A. Waspadai Benjolan

Membesar dan Tidak Sakit avalaible online at http://kesehatan.kompasiana.com/med is/2012/06/08/waspadai-benjolanmembesar-dan-tidak-sakit468261.html [Accessed 19 Oktober 2012]

9. Wijaya LV, Gunawan D, Oroh E Ch, Kapantow MG. Tumor Kulit Jinak di Poliklinik Kulit dan Kelamin RSUP Prof. dr. R. D. Kandou Manado. Media Dermato- Venereologica Indonesia . Vol. 38.No.2 Tahun 2011: 70-79.

10. Kolegium Ilmu Kesehatan Kulit dan Kelamin Indonesia. Standar kompetensi dokter spesialis-1 ilmu kesehatan kulit dan kelamin. Jakarta, 2007: p. 47-50.
11. Department of International Economic and Social Affairs. United Nations. Provisional guidelines on standard international age classifications. New York, 1982: p. 27

12. Thomas VD, Swanson NA, Lee KK. Benign epithelial tumors, hamartomas, and hyperplasias. Dalam: Wolff K, Goldsmith LA, Katz SI, Gilchrest BA, Paller AS, Leffel DJ. Fitzpatrick's Dermatology in General Medicine; edisi ke-7. New York: The McGraw-Hill Companies, 2008: p. 1054-67.

13. Yaar, Mina, Gilchrest BA. Aging of skin. Dalam: Wolff K, Goldsmith LA, Katz SI, Gilchrest BA, Paller AS, Leffel DJ. Fitzpatrick's Dermatology in General Medicine; edisi ke-7. New York: McGraw Hill, 2008: 963-1198. 